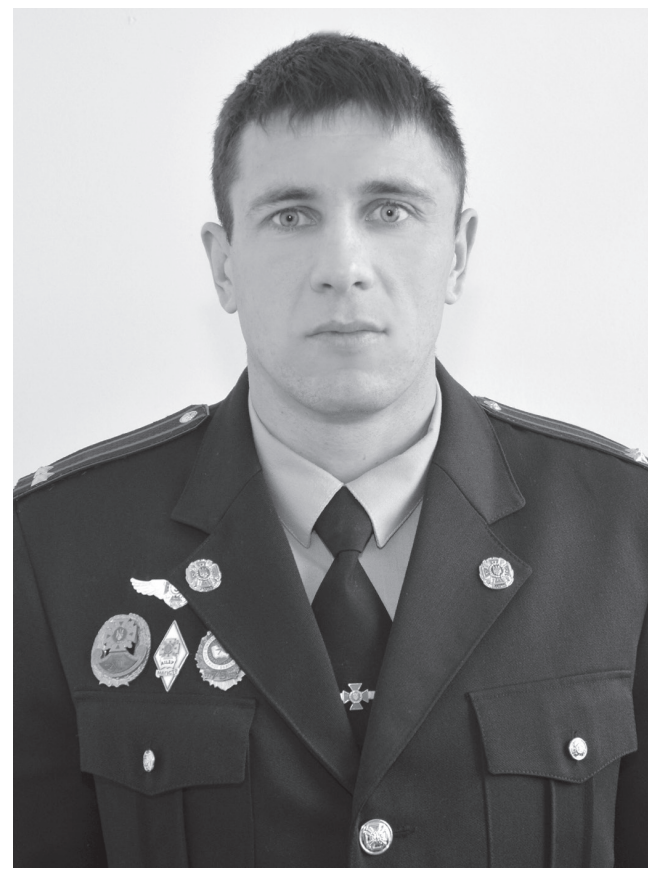
ning, National University of Civil Defense of Ukraine, 61023, Kharkiv, Str. Chernyshevska, 94, tel.: (057) 70031 71, e-mail: nuczu@mns.gov.ua

ORCID: 0000-0002-6396-9906

\title{
ВНУТРІШНІ РИЗИКИ СУЧАСНОГО СТАНУ ВИщОї ОСВІТИ в УКРАїHI
}

Анотація. Розглянуто проблему управління внутрішніми ризиками, які впливають на українські навчальні заклади. Проаналізовано існуючі внутрішні виклики та ризики в системі вищої освіти України. Розкрито сутність кластерного підходу, який на сьогодні є доволі ефективним засобом подолання проблем економічного механізму державного управління в системі реформування та розвитку вищої освіти.

Визначено, що однією з найбільш складних і важливих проблем внутрішніх ризиків виступає кадровий ризик. Вирішення цієї проблеми приведе до посилення конкурентоспроможності вищих освітніх закладів та ефективності усього освітнього процесу загалом.

Доведено, що управління внутрішніми ризиками є важливим питаням, яке має вирішуватися не лише з навчальним закладом, а й усією системою освіти країни. Підкреслено важливість підвищення освітніх послуг за допомогою досягнення оптимального стану внутрішнього середовища освітньої установи. Управління внутрішніми ризиками вищого навчального закладу має базу- 
ватися на загальноприйнятих підходах, враховувати специфіку сфери освіти та конкретну класифікацію ризиків і викликів.

Досліджено особливості кластерного підходу в освіті. Визначено, що кластерний підхід забезпечує концентрацію управлінських зусиль освітніх установ на рішення виховних завдань, тим самим сприяючи зниженню внутрішніх ризиків у вищому навчальному закладі. Обгрунтовано, що впровадження кластерного підходу в діяльність освітнього закладу буде підвищувати якість та соціальний статус професійної освіти, а також підвищувати потребу випускників на ринку праці.

Сучасний розвиток системи освіти передбачає врахування положень ризик-менеджменту, спрямованого на подолання наявних внутрішніх проблем та викликів, тим самим забезпечуючи інноваційний розвиток вітчизняних університетів й підвищуючи конкурентоспроможність вітчизняної освіти на світовому ринку.

Ключові слова: внутрішні ризики, фінансові ризики, інноваційні ризики, кадрові ризики, державне управління, кластерний підхід.

\section{ВНУТРЕННИЕ РИСКИ СОВРЕМЕННОГО СОСТОЯНИЯ ВЫСШЕГО ОБРАЗОВАНИЯ В УКРАИНЕ}

Аннотация. Рассмотрена проблема управления внутренними рисками, влияющими на украинские учебные заведения. Проанализированы существующие внутренние вызовы и риски в системе высшего образования Украины. Помимо этого раскрывается сущность кластерного подхода, который на сегодня является одним из эффективных средств преодоления проблем экономического механизма государственного управления в системе реформирования и развития высшего образования.

Определено, что одной из самых сложных и важных проблем внутренних рисков выступает кадровый риск. Решение данной проблемы приведет к усилению конкурентоспособности высших образовательных учреждений и эффективности всего образовательного процесса в целом.

Доказано, что управление внутренними рисками является важным вопросом, который должен решаться не только учебным заведением, но и всей системой образования страны. Подчеркнута важность повышения образовательных услуг посредством достижения оптимального состояния внутренней среды образовательного учреждения. Управление внутренними рисками высшего образовательного учреждения должно базироваться на общепринятых подходах, учитывать специфику сферы образования и конкретную классификацию рисков и угроз.

Исследованы особенности кластерного подхода в образовании. Определено, что кластерный подход обеспечивает концентрацию управленческих усилий образовательных учреждений на решение воспитательных задач, тем самым способствуя снижению возникающих внутренних рисков в высшем учебном заведении. Обосновано, что внедрение кластерного подхода в деятельность образовательного учреждения будет повышать качество и соци- 
альный статус профессионального образования и увеличивать востребованность выпускников на рынке труда.

Современное развитие системы образования предполагает учет положений риск-менеджмента, который будет направлен на преодоление имеющихся внутренних проблем и вызовов, тем самым обеспечивая инновационное развитие отечественных университетов и повышая конкурентоспособность отечественного образования на мировом рынке.

Ключевые слова: внутренние риски, финансовые риски, инновационные риски, кадровые риски, государственное управление, кластерный подход.

\section{INTERNAL RISKS OF THE CONTEMPORARY STATE OF HIGHER EDUCATION IN UKRAINE}

Abstract. This article is devoted to the problem of managing internal risks affecting Ukrainian educational institutions. The author analyzes the existing internal challenges and risks in the system of higher education in Ukraine. In addition to this, the essence of the cluster approach, which is one of the effective means of overcoming the problems of the economic mechanism of public administration in the system of reform and development of higher education, is being revealed.

The author suggests that people risk is one of the most difficult and important problems of internal risks. It is noted that the solution of this problem will lead to an increase in the competitiveness of higher educational institutions and the effectiveness of the entire educational process.

It is proved that the management of internal risks is an important issue that is to be decided not only by the educational institution, but also by the entire education system of the country. The author shows the importance of improving educational services by achieving an ideal state of the internal environment of the educational institution. It is shown that the management of internal risks of a higher educational institution should be based on generally accepted approaches, take into account the specifics of the education sphere and a specific classification of risks and threats.

Also, the author examines the features of the cluster approach in education. It is determined that the cluster approach ensures the concentration of management efforts of educational institutions to solve educational problems, thereby contributing to the reduction of emerging internal risks in a higher educational institution. It is substantiated that the introduction of the cluster approach in the activity of the educational institution will improve the quality and social status of vocational education and increase the demand for graduates in the labor market.

In conclusion, the author says that the modern development of the education system presupposes taking into account the provisions of risk management that will be for overcoming existing internal problems and challenges, thereby ensuring the creative development of domestic universities and increasing the competitiveness of domestic education in the world market.

Keywords: internal risks, financial risks, innovative risks, people risks, public administration, cluster approach. 
Постановка проблеми. Питання управління ризиками займають важливе місце в управлінні господарською діяльністю різних організацій. Не дивлячись на специфічний ринок послуг закладів вищої освіти, ці проблеми не обходять стороною й вищі навчальні заклади.

Головна задача управління ризиками у цій сфері полягає в оптимальному забезпеченні відношення між бажаним рівнем ризику та необхідними для цього грошовими затратам. У зв'язку з цим система управління ризиками закладів вищої освіти повинна забезпечувати необхідний механізм подолання проблем, які викликаються ними.

Серед складових цієї системи слід виокремити процедуру прийняття рішень у випадку наявності ризику, а також вибір методів його запобігання, визначення відповідальних осіб, інформаційну систему управління та систему внутрішнього контролю. Управління внутрішніми ризиками закладів вищої освіти становить одне з важливих питань, які вирішуються керівництвом закладу. Унаслідок високого зростання конкуренції на ринку освітніх послуг важливо, щоб стан внутрішнього середовища навчального закладу був максимально оптимальним. Для цього необхідно здійснювати безперервний моніторинг усіх внутрішніх механізмів закладів вищої освіти, а також, при оцінці ситуації, своєчасно розпізнавати вплив внутрішніх ризиків на ефективність управління вищим навчальним закладом.

Аналіз останніх публікацій за проблематикою. Дослідженням ризиків присвячені роботи багатьох теоретиків-класиків, а саме: А. Гана, Дж. Кейнса, А. Сміта, I. Фішера.

Щодо вивчення проблем, пов'язаних з внутрішніми ризиками системи вищої освіти, ними також займалися і вітчизняні вчені, серед яких Т. Боголиб, А. Таркуцяк, В. Гельман та ін.

Однак, незважаючи на широкий спектр досліджень, які були проведені у цій сфері, на сьогодні ми бачимо недостатність висвітлення питань оцінювання ступеня впливу внутрішніх ризиків на управління закладом вищої освіти.

Метою статі є дослідження внутрішніх ризиків, які стоять перед закладами вищої освіти 3 позиції їх управління та подолання існуючих проблем.

Виклад основного матеріалу. Серед основних внутрішніх ризиків, які залежать від внутрішніх ресурсних та управлінських факторів, ми можемо виділити недостатність таких ресурсів, а особливо, студентів, висококваліфікованого персоналу, фінансів, комп'ютерної техніки, інфраструктури тощо. Це все при тому, що нині ми спостерігаємо неефективний процес управління використанням цих ресурсів при достатньо складних зовнішніх умовах [1].

Нормативні постанови Кабінету Міністрів України передбачають ті критерії, які виступають як основа для оцінки ступені ризику окремого навчального закладу для системи загальносередньої, професійно-технічної та вищої освіти. Серед критеріїв для оцінювання рівня ризику у сфері вищої освіти можна виділити терміни ведення господарської діяльності, яка надає освітні послуги в системі вищої освіти, факти порушення 
вимог законодавства для ведення господарської діяльності, яка забезпечує освітні послуги у системі вищої освіти. До таких порушень слід віднести: відсутність правових основ для ведення освітньої діяльності окремих напрямів та спеціальностей, ті або інші порушення вимог, які висуваються до формування структури закладу вищої освіти та контингенту студентів, чи кадровому забезпеченню навчального процесу, або невиконання навчального плану та програми. Не менш важливими критеріями для оцінювання рівня ризиків будуть виступати результати акредитації освітніх програм, планові показники діяльності, які містяться у щорічних планах суб'єкта господарювання, наприклад, державне замовлення та фінансова стабільність.

Такі критерії, звичайно, аналізують при перевірці закладів вищої освіти, і на цій основі роблять висновок про ступінь його ризику, який може бути незначним, середнім чи високим. 3 наукової точки зору серед цих проблем дуже важливими будуть виконання державного замовлення та фінансова стабільність, але необхідно також враховувати більш комплексну оцінку та розширення кола критеріїв, серед яких співвідношення фактичного контингенту та ліцензованих об'ємів, рівень безробіття випускників у регіоні та загалом. Важливо також оцінити ступінь ризику різних рівнів, у тому числі самого закладу, регіону, підгалузі або галузі взагалі [2].

3 метою детального аналізу механізмів керування ризиками закладів вищої освіти необхідно розглянути елементарні внутрішні ризики.
Серед них одним із важливих можна назвати ризик недостачі зворотних коштів. Грошові кошти, які знаходяться в обороті, виступають джерелом такого ризику. Зауважимо, що грошові кошти від оплати студенів за послуги освіти надходять до закладів вищої освіти нерівномірно, оскільки оплата проходить одним платежем на початку отримання послуги або два рази на рік, однак затрати на функціонування закладів освіти здійснюються постійно. У випадку проведення неправильної управлінської фінансової політики з'являється недостача зворотних грошових коштів у той період, коли не проходить оплата за навчання.

Ще однією умовою виникнення цього ризику може виступати недостача коштів в обороті, яка призводить до негативних наслідків, серед яких потреба в кредиті чи займу, з метою встановлення балансу грошових коштів в обороті. Тому для раціонального управління грошовими коштами в обороті необхідно проводити їх оптимізацію, яка опирається на потреби закладу. Важливою задачею управління грошовими коштами в обороті буде виступати забезпечення їх джерелами фінансування. Це говорить нам про те, що на першому плані мають стояти методичні та практичні питання управління процесами аналізу, а також необхідність рішення проблеми формування та раціонального використання оборотних коштів.

Забезпечення рівномірного розподілу затрат закладу залежить від правильної фінансово-економічної політики навчального закладу, з урахуванням нерівномірного надхо- 
дження грошових коштів. Тому існує необхідність створити відповідний резерв для певних обов'язкових потреб та затрат закладу освіти, опираючись при цьому на показники та прогнози загальноекономічної ситуації в країні, розраховуючи суму оплати за навчання. Правильне визначення суми оплати за весь період навчання, а також їі розподіл по курсам рівними частинами або рівномірно збільшуючи кожного року, є одним із важливих напрямів фінансово-економічної політики навчального закладу. Існує також необхідність враховувати той варіант, коли студент проводить завчасну оплату всього періоду навчання. У цьому випадку важливо правильно направити потік керованих грошових коштів. Серед можливих варіантів ми можемо виділити депозитні вклади, інвестиції у довготривалі проекти або видачу сертифікатів на навчання. Усе це говорить про те, що ефективний розподіл та здійснення вкладення грошових коштів для забезпечення потреб закладу упродовж усього періоду навчання студентом, буде приносити максимальний прибуток [3].

Серед внутрішніх фінансових ризиків виділяються інвестиційні, які для закладів вищої освіти насамперед пов'язані з інноваційною діяльністю. Така діяльність закладів вищої освіти становить організацію навчального, науково-інноваційного процесу в чотирьох напрямах, а саме: освітній, науково-дослідницький, адміністративно-управлінський, науково-технічний. 3 метою управління інвестиційними ризиками необхідно здійснювати їх своєчасне виявлення, оцінювати та аналізувати виявлені ризики, визначати причини їх появи, розробляти заходи, які будуть зменшувати їх вплив, економічно обгрунтовувати та реалізовувати розроблені заходи. Виконання таких етапів дасть можливість підвищувати ефективність управління інвестиційними ризиками.

Вважаємо, що серед специфічних внутрішніх ризиків необхідно назвати втрати контингенту, який, зазвичай, класифікують як операційний. Природно, що основним і єдиним споживачем послуг закладів вищої освіти є студенти. Абітурієнти формують потенційний контингент у вищому закладі освіти. Останнім часом спостерігається така тенденція, яка полягає у нехватці абітурієнтів, яку можна пояснити демографічною ситуацією в країні, політикою зі сторони держави, фінансовою неспроможністю населення. Усі ці фактори впливають на значне скорочення кількості абітурієнтів, що, своєю чергою, змушує заклади вищої освіти підсилювати конкурентну боротьбу за них. Наслідки такого ризику впливають на усі види діяльності закладу вищої освіти, найперше, на його фінансовий стан [4].

Нині ми можемо бачити, що аналітики МОН України пропонують нам кластерний підхід, який дає можливість визначити регіональні групи закладів вищої освіти відносно міри загострення їх внутрішніх проблем.

Важливими ознаками учасників кластера є наявність так званої "критичної маси”, а також достатньо підвищений рівень зв'язків між учасниками, тобто внутрішній і зовнішній зв'язок та новизна в активності учасників кластера. Якщо розглядати ос- 
танній компонент, слід зазначити, що кластер спрямований та сконцентрований на інноваційно-активні підприємства (фірми та установи). Саме інноваційний розвиток спрямовує діяльну орієнтацію цих структур та визначає інноваційну активність, що досягається постійним удосконаленням переваг у результаті різних видів нововведень. До таких можна віднести організаційні, технологічні, технічні та маркетингові нововведення.

Підводячи підсумок сказаного, зазначимо, що вирішити проблему виробничої взаємодії саме у галузі підготовки класифікованої робочої сили можливо за рахунок кластеризації сфери освіти. У даному випадку такий підхід допоможе підвищити конкурентоспроможність на регіональному та національному рівнях, підвищити ріст інноваційного потенціалу, розвивати малий та середній бізнес у сфері освіти та підготовки кваліфікованих працівників, а також і в інших сферах.

Накопичений досвід говорить нам про те, що саме кластерний підхід не лише є засобом досягнення мети, що ставилась та поєднана 3 підвищенням конкурентоспроможності, а й з інноваційним підсиленням, що також представляє собою дієвий засіб, що є стимулом регіонального розвитку, який дасть змогу отримати мультиплікаційний ефект і приведе до збільшення зайнятості, підвищить рівень заробітної плати, а також відрахувань у бюджет та зростання стабільності у конкуренції областей та держави загалом [5].

Якщо розглядати центри, де можуть формуватися кластери, то це можуть бути навчальні заклади, зо- крема заклади вищої освіти та окремі групи наукових і дослідних організацій. У такому випадку кластери будуть розглядатися як найбільш ефективна виробнича система в умовах глобалізації та розвитку сучасної науки, тобто це економіка знань [6].

Розглядаючи сферу розвитку регіонів, слід зазначити, що тут варто розвивати кластерні концепції. У такому випадку потрібно провести на національному рівні радикальні реформи, що приведуть до розширення організаційного та економічного співробітництва. При цьому основним аспектом супроводження процесу кластеризації є реалізація політики на загальнодержавному рівні, яка спрямовуватиметься на підтримання та розвиток науково-технічного прогресу, інновацій, проведення адміністративних, фінансових та економічних, а також регуляторних реформ та стратегічний розвиток регіонів [7].

На думку Т. Ю. Краснікової, освітні кластери становлять систему об'єднаних установ спеціалізованої освіти, що поєднані за галузевою ознакою та мають партнерські відносини з підприємствами цієї галузі [8].

Якщо розглянути твердження Н. В. Васильєвої, то слід зауважити, що освітній кластер на рівні регіону, потрібно розглядати як цілу систему освітніх закладів 1-4-го рівнів акредитації, комерційних компаній, організацій, що займаються введенням новацій в інфраструктуру на регіональному рівні та рівні підтримки підприємництва, що перебувають у тісному зв'язку з владою та компонентною економічною системою. На ряду з цим, вона стверджує, що центром або ядром кластера може 
виступати заклад вищої освіти, який буде брати на себе відповідальність у напрямі освітньої та наукової підтримки кластера, а також одночасно представляти собою інформаційно-методичний центр та комунікаційну платформу [9].

Н. А. Корчагіна доводить, що для отримання освітньої послуги, яка $€$ кінцевим продуктом діяльності, освітній кластер має представляти собою групу освітніх закладів, які розташовані в одному регіоні та перебувають у партнерських відносинах. При такому підході центром освітнього кластера буде заклад вищої освіти або інша організація освітнього напряму [10].

Освітній кластер у розумінні О. В. Смірнова - це інноваційний ланцюг "наука - технологія - бізнес", що зв’язаний горизонтально всередині між собою та є системою навчання, взаємонавчання, а також інструментів самонавчання. При такому підході основу освітнього кластера складає освітній процес, який дає змогу розглядати цей кластер з двох боків: як систему і як процес [11].

Проте освітній кластер необхідно розглядати як більш ємне щодо ринку освітніх послуг, поняття. Тобто це система взаємопов'язаних вищих закладів освіти та освітніх організацій, значущість яких доволі велика. Означене поняття може визначатися 3 такими формами інтеграції між галузями, як спільні підприємства, холдингові структури, стратегічні альянси, мережеві об'єднання, технопарки, промислові парки, економічні зони.

На нашу думку, освітній кластер - це більш складний процес, ніж звичайне об'єднання закладів освіти, організацій та підприємств, тому що дані заклади беруть участь у процесі кооперації та конкурують один з одним.

Процес безперервної освіти, починаючи від дошкільного закладу, далі від школи і аж до самого виробництва, становить одну систему, що в результаті утворює освітній кластер.

Крім цього, слід зазначити, що освітній інноваційний соціокультурний кластер являє собою близькі взаємодіючі суб'єкти господарювання, що добровільно об'єднані географічно, та включають в себе: освітні заклади, органи влади, банківський та приватний сектор, інноваційні організації, різні об'єкти інфраструктури, які включають в себе виробництво конкурентоспроможних освітніх, соціальних та культурних послуг, спрямованої стратегії розвитку на реалізацію інтересів усіх учасників, а також території локалізації кластера, де вона перебуває та має важливу соціально-економічну роль для регіону. Мета створення кластера - об'єднання зусиль, можливостей, потенціалу суб'єктів нової структури для здійснення взаємоузгоджених дій, що будуть спрямовані на підвищення якості рівня освіти в регіонах, iii конкурентоспроможність як на вітчизняному, так і світовому рівнях.

Підводячи підсумок, можна сказати, що під поняттям освітнього кластера треба розуміти союз, пов'язаних між собою та територією, закладів вищої освіти, що приводить до розвитку та зростання конкурентоспроможності кожного з них, а їх діяльність спрямована на досягнення інноваційних технологій та якості підготов- 
ки працівників для регіонального та національного ринку праці.

Висновки та перспективи подальших досліджень. Таким чином, в економічному механізмі державного управління в системі реформування та розвитку вищої освіти в Україні ми можемо побачити необхідність змін вітчизняної системи вищої освіти у сфері їі готовності відносно сучасного розвитку, серед яких нові підходи до виділення не лише освітніх, а й освітньо-наукових кластерів.

Також можна говорити про неадекватність реакції на виклики та ризики зовнішнього та внутрішнього середовища на інституційному, регіональному та національному рівнях.

Це все при тому, що нині ми спостерігаємо у сфері вищої освіти великі глобальні, політичні та економічні виклики, які зумовлені загальносвітовою тенденцією та специфічними умовами сьогодення, що дає нам можливість зробити висновок про необхідність своєчасного та обгрунтованого аналізу таких викликів та ризиків, які є основою для розроблення обдуманих та дієвих рішень для їх реалізації у державній освітній політиці. Ми можемо сказати, що вітчизняна вища освіта має значний запас міцності, який важливо не лише зберегти, а й примножити. Сучасний етап розвитку передбачає формування професійного ризик-менеджменту у системі вищої освіти, оскільки сучасний інноваційний розвиток українських університетів та усієї освітньої системи може бути забезпечений тільки тоді, коли ми будемо передбачати події, а не діяти в режимі реагування на ті чи інші ризики.

\section{СПИСОК ВИКОРИСТАНИХ ДЖЕРЕЛ}

1. Заярная И. А. Влияние внутренних рисков на управление вузами // Фундаментальные исследования. 2014. - № 6-4. - С. 785-788.

2. Вавренюк С. А. Государственное регулирование реформирования высшего образования Украины на современном этапе / С. А. Вавренюк // East journal of security studies: наук. журнал. - Х.: Изд-во НУЦЗУ; Гданьск (Польша), 2018. - Вып. 2 (12). - C. 15-24.

3. Селезнева Н. А. Качество высшего образования: опыт системного исследования. // Матер. междунар. науч.-теорет. конф. "Национальная система оценки качества образования: проблемы, стратегия, технология”. - Тараз: Тараз. ун-т, 2003. C. 32-54.

4. Греченко Д. А., Чулюков В. А. Структурная компонента модели организационного управления высшим учебным заведением // Современные наукоемкие технологии. 2010. - № 4. - С. 13-16.

5. Инновации в управлении вузом: новые решения для корпоративной информационной системы / И. О. Красильников и [др.] // Университет. упр. - 2014. - № 6 (46). C. $16-24$.

6. Каленюк I. С. Сучасні ризики розвитку вищої освіти в Україні / I. С. Каленюк, О. В. Куклін, В. А. Ямковий / / Економіка України. - 2015. № 2. - С. 70-83.

7. Домбровсъка С. М. Механізми реалізації державної політики в галузі вищої освіти / С. М. Домбровська // Актуальні пробл. держ. упр. 2011. - № 2. - С. 107-113.

8. Красикова Т. Ю. Образовательный кластер как фактор взаимодействия рынка труда и системы высшего профессионального образования / 
Т. Ю. Красикова // Актуальные вопр. экономики и упр.: материалы междунар. науч. конф., апрель 2011 г.: тезисы докл. - М.: РИОР, 2011. - T. II. - C. 54-59.

9. Васильева Н. В. Формирование и развитие образовательных кластеров в региональной социально-економической системе: автореф. ... канд. экон. наук: спец. 08.00.05 “Экономика и управление народным хазяйством (региональная экономика)" / Н. В. Васильева. - Гатчина, 2013. $26 \mathrm{c}$.

10. Корчагина H. А. Образовательные кластеры как основа повышения конкурентоспособности учебных заведений / Н. А. Корчагина / / Прикаспийский журн.: упр. и высокие технологии. - 2009. - № 3 (7). С. 78-84.

11. Смирнов A. B. Образовательные кластеры и инновационное обучение в вузе: монография / А. В. Смирнов. - Казань: РИЦ “Школа", 2010. - 102 c.

\section{REFERENCES}

1. Zayarnaya I. A. (2014). Vliyanie vnutrennih riskov na upravlenie vuzami [Influence of internal risks on the management of universities]. Fundamental research. № 6-4. p. 785-788.

2. Vavrenyuk S. (2018). Gosudarstvennoe regulirovanie reformirovaniya vysshego obrazovaniya Ukrainy na sovremennom etape [State regulation of the reform of higher education in Ukraine at the present stage]. Est journal of security studies: Sciences. Journal. Vip. 2 (12). p. 15-24.

3. Selezneva N. A. (2003). Kachestvo vysshego obrazovaniya: opyt sistemnogo issledovaniya [The quality of higher education: the experience of system research]. Mater. Int. scientific-theor. Conf. National system for assessing the quality of education: problems, strategy, technology. Taraz: Taraz University, p. 32-54.

4. Grechenko D. A., Chulyukov V. A. (2010). Strukturnaya komponenta modeli organizacionnogo upravleniya vysshim uchebnym zavedeniem [Structural component of the model of organizational management of higher education institutions]. Modern high technology. № 4. p. 13-16.

5. Krasilnikov I. O. et all. (2014). Innovacii v upravlenii vuzom: novye resheniya dlya korporativnoj informacionnoj sistemy [Innovations in university management: new solutions for the corporate information system]. University management. № 6 (46). p. 16-24.

6. Kaleniuk I. S. (2015). Suchasni riziki rozvitku vishoyi osviti v Ukrayini [Modern Risks of the Development of Higher Education in Ukraine], Economics of Ukraine. 2. p. 70-83.

7. Dombrozska S. N. (2011). Mehanizmi realizaciyi derzhavnoyi politiki v galuzi vishoyi osviti [Mechanisms for the implementation of state policy in the field of higher education]. Actual problems of public administration. № 2. p. 107-113.

8. Krasikova T. Yu. (2011). Obrazovatelnyj klaster kak faktor vzaimodejstviya rynka truda i sistemy vysshego professionalnogo obrazovaniya [Educational cluster as a factor in the interaction of the labor market and the system of higher professional education]. Actual problems of economics and management: materials of the international. sci. Conf., April 2011: theses additional. Vol. II. p. 54-59.

9. Vasilyeva N. V. (2013). Formirovanie i razvitie obrazovatelnyh klasterov $\mathrm{v}$ regionalnoj socialno-ekonomicheskoj sisteme: avtoref. na soiskanie uchenoj stepeni kand. ekon. nauk: specialnost 08.00.05 "Ekonomika i upravlenie narodnym hazyajstvom (regionalnaya ekonomika)" [Formation and deve- 
lopment of educational clusters in the regional socio-economic system: the author's abstract for the academic degree of Cand. econ. Sciences: specialty 08.00.05 "Economics and management of the national economy (regional economy)"]. Gatchina. Poland.

10. Korchagina N. A. (2009). Obrazovatelnye klastery kak osnova povysheniya konkurentosposobnosti uchebnyh za- vedenij [Educational clusters as a basis for increasing the competitiveness of educational institutions]. Prikaspiysky Journal: Management and High Technologies. № 3 (7). p. 78-84.

11. Smirnov A. V. (2010). Obrazovatelnye klastery $\mathrm{i}$ innovacionnoe obuchenie $\mathrm{v}$ vuze: monografiya [Educational Clusters and Innovative Education in the University: Monograph]. Kazan. 